\title{
COINING NONCE WORDS: CONTRASTIVE RESEARCH BASED ON A NOVEL
}

\author{
Svetlana Nedelcheva \\ Department of English Studies, \\ Konstantin Preslavsky University of Shumen, Bulgaria
}

\begin{abstract}
Nonce words or occasionalisms are coined for a particular occasion and usually they are used just once. It is especially difficult when such newly created words have to be translated to another language. This article studies John Harding's novel Florence \& Giles and its Bulgarian translation (by Vladimir Molev). It is a sinister Gothic story told by the 12-year-old Florence living in an isolated New England mansion in 1891. She distorts words by transforming them into other parts of speech, e.g. nouns and adjectives are turned into verbs, nouns into adjectives, adverbs and prepositions into verbs, etc. At first, it could be annoying to the reader, however, once you get used to her narration, it is both fanciful and charming. This research studies the intensely concentrated nonce words in the text and their equivalents in Bulgarian from the point of view of their grammatical, word-formative and semantic characteristics. The contrastive method when applied to the parallel corpus shows some similarities and a lot of differences in the particular characteristics of nonce words due to the specifics of the two languages under discussion.
\end{abstract}

Keywords: nonce words (occasionalisms), word-formation, grammatical features, parallel corpus, Florence \& Giles

\footnotetext{
About the author: Svetlana Nedelcheva is an Associate professor of English linguistics at Konstantin Preslavsky University of Shumen, Department of English Studies. She has published two monographs Cognitive Interpretation of the English Preposition ON and Space, Time and Human Experience: A Cognitive View on English and Bulgarian Prepositions, two course books English Morphology - Traditional and Cognitive Perspective and Essential English Syntax for University Students, and research articles in the field of cognitive linguistics, contrastive linguistics, translation studies and foreign language teaching. She has specialized in a number of universities, e.g., the University of Bangor, UK (Post-Doctoral Research Program) and Georgetown University, USA (as a Fulbright researcher).
}

e-mail: s.nedelcheva@shu.bg

ORCID iD: https://orcid.org/0000-0003-1614-8758

Copyright (c) 2021 Svetlana Nedelcheva

Article history: Received: 2 April 2021; Reviewed: 16 July 2021; Revised: 19 July 2021; Accepted: 22 July 2021; Published: 31 August 2021

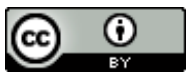

This open access article is published and distributed under a Creative Commons Attribution 4.0 International License.

Citation (APA): Nedelcheva, S. (2021). Coining nonce words: Contrastive research based on a novel. Studies in Linguistics, Culture, and FLT, 9(2), 7-29. https://doi.org/10.46687/MLSR6834 


\section{Introduction}

Florence \& Giles is an ominous Gothic tale set in a distant and dilapidated New England mansion. Two orphaned half-siblings (Florence and Giles share only a father) live there ignored by their guardian uncle but under the daily care of domestic staff. The staff is all newly employed and there is very little information about the family history. At the beginning, the children live in isolated existence and although their uncle never visits them, he provides for their needs. Under his instruction the 12-year-old Florence is not to be educated but in spite of his will she has educated herself by secretly devouring the books that remain untouched on the dusty and neglected shelves hidden away in the library. She has taught herself languages she had never heard spoken. Inspired by the works of Dickens, Trollope and her true love, Shakespeare, Florence has developed a unique language of her own. She narrates her own story in a fairly unusual style. At first the reader could be a little vexed and distracted because of Florence's unique style of communicating, however, as she is persistent in the use of her nonce words, the reader also gets used to her narration.

The two children enjoy each other's company until Giles is sent away to school. Then Florence meets the neighbouring boy, Theo, and becomes friends with him. She has no time to feel lonely as her day and night are full of events. By day, she confines to her hidden place to read. By night, she sleepwalks the corridors. She is haunted by a repeated dream in which a strange woman endangers her younger brother Giles's life. Sometimes Florence just pretends to sleepwalk so that she can search the house for some information about her unknown past. Suddenly, Giles returns home because he is bullied at school and is to be educated by a governess. The first governess, Miss Whittaker, doesn't last long before she "tragicks upon the lake". After her unexpected death a second teacher, Miss Taylor, arrives, and Florence is immediately convinced that the new governess is an evil spirit who means to hurt Giles. She takes on the extremely risky task to outsmart and expose her. In order to defeat this mighty supernatural fiend, and with no adult to help her, Florence must use all her brainpower and ingenuity to save her little brother and protect her own world. No further details about the plot are necessary to persuade the reader that Florence \& Giles is a gripping Gothic story narrated in a surprisingly different and remarkably fascinating voice. This startling narrative voice is the focus of the present article, more specifically the numerous nonce words invented by Florence and their equivalents in the Bulgarian translation of the book. We study the grammatical, word-formative and semantic characteristics of the nonce words used in both the original of the book and its translation. 


\section{Theoretical background}

Nonce words are a subtype of neologisms. By definition they do not require to be widely known or permanent. They are seen as spontaneously coined for a specific situation. The corresponding Bulgarian term is оказионализми / occasionalisms. Similarly to neologisms they are time dependent as they are comparatively recent phenomena that may be in a process of being accepted as mainstream words. According to Linguistics Encyclopedia (2006, p. 601), nonce-formation "is a neologism used in just one occasion" and "will not become a regularly used linguistic item". Defined as vocabulary units that are unusual, nonce or occasional words do not conform to conventional language rules, because they are characterized by a certain individual meaning determined in a specific context. Thus nonce words are considered as speech phenomena which do not correspond to standard language, their meaning depends on the context and they express the personal opinion of the speaker.

Whereas neologisms refer to new objects and facts of language and they originate from the communicative needs of the society, nonce words are claimed to be "individual author's coinages created according to unusual or unproductive wordformative patterns, the facts of speech which stem from the aims of the utterance and the context, outside of which they are rarely used" (Holtvian \& Severynchuk, 2015, p. 213). Sometimes these two types of language units also differ in their function. The main function of neologisms is to denote new objects, phenomena, etc. The central function of the nonce words is the expressive one. They are invented and used for artistic purposes to describe a fictional reality and attract the readers' attention.

Therefore, considering the specifics of nonce words, it is possible to indicate the following features: 1 . Nonce words are created to serve the purposes of a specific situation; 2 . Their newness and unusualness to listeners and readers is what distinguishes nonce words from neologisms which gradually lose their novelty over time; 3 . The appearance of nonce words is unpredictable; 4. An inherent feature of nonce words is their high expressiveness due to the freshness of perception and originality (cf. Gorchhanova, 2016).

Sources of nonce vocabulary units are fiction books and short stories, e.g. "grok" (to understand using intuition) from Robert A. Heinlein's novel Stranger in a Strange Land; "McJob" (low-paid job) from Douglas Coupland's Generation X: Tales for an Accelerated Culture; "cyberspace" (digital network) from William Gibson's Neuromancer, etc. Sometimes titles of books become neologisms, for instance, Joseph Heller's Catch-22 (a paradoxical situation from which there is no way out). Alternatively, an author's name may give rise to a neologism

1. Such neologisms are used by Carroll in the poem Jabberwocky from Through the Looking-Glass. 
or a famous character of a novel, e.g., "Orwellian", originating from George Orwell's name and related to his dystopian novel about a future totalitarian state Nineteen Eighty-Four; "quixotic", referring to someone or something which is idealistic and impractical in relation to Miguel de Cervantes' romantic character Don Quixote; "scrooge", a character from Charles Dickens' A Christmas Carol who hates spending money. A nonce word is found in Iliad, namely $\pi \alpha v \alpha \omega ́ p 1 o \zeta$ (Pope, 1985). The word's uniqueness provoked different interpretations, and the standard translation 'of all-untimely fate' or 'doomed to die young' raises objections. Pope (1985) argues what Achilles means by 'untimely' is that he is a misfit, someone who is always at the wrong place at the wrong time.

Recent studies explore the author's new formations and their analogies in the translations of Terry Pratchett's novels, Joan K. Rowling's Harry Potter series and J. R. R. Tolkien's The Lord of the Rings trilogy, among others. Some of the discussed problems refer to translating symbolic names (so-called speaking names) of recurrent characters from English into Bulgarian in Terry Pratchett's Discworld series (Boyadzhieva, 2017), some "deeply meaningful" personal names, toponyms and nicknames from English into Bulgarian in J. R. R. Tolkien's The Fellowship of the Ring (Nedelcheva, 2017), as well as the system of proper names in J. R. R. Tolkien's Lord of the Rings from English into Russian as individual neologisms, which allow to represent the author's mythology (Lugovaya, 2019).

Further research deals with translation features of occasionalisms by J. Rowling in Harry Potter and the Damned Child, based on translations from English into Chinese, more specifically lexical analysis is given of the word-formation structure of spells in the text of the original and in the translated text, as well as the ways of their transmission from the source to the target language (Starikova, 2019). Translatability issues are considered in relation to wordplay and the loss of humorous effect in the Bulgarian translation of Terry Pratchett's Soul Music (Iglikova, 2013), as well as the process of unveiling the main characteristics of occasionalisms and their ways of derivation, based on J.R.R. Tolkien's Lord of Rings and The Two Towers and its Russian translation (Petrov, 2019).

Other articles focus on identifying and describing phonetic occasionalisms ${ }^{2}$ in structural and semantic aspects (Romanyuk, 2019a) or analyzing the features of the modern English occasional words in the works of J. Rowling and systematizing them according to non-standard models (Romanyuk, 2019b). A previous study on the occasionalisms in Florence \& Giles' Bulgarian translation points out grammatical, semantic and word-formative aspects of these novel Bulgarian words (Savova, 2016). The present article adds to the previous re-

2. Phonetic occasionalisms are combinations of phonemes which are not registered in the language. 
search by studying the morphological and lexicological characteristics of the English nonce words in John Harding's book Florence \& Giles and compares and contrasts them with their Bulgarian equivalents. Traditionally, occasionalisms are commented on in view of their uniqueness and expressiveness, in this novel, however, a number of nonce words are used repeatedly as part of the main character's idiolect. These "strange words" invented by Florence are not art for the art's sake. They conform to the author's idea of Florence's characterbuilding. She would like to be a writer and she is inspired by Shakespeare and his "way with words" (Harding, 2010, p. 6):

The thing I liked most about Shakespeare was his free and easy way with words. It seemed that if there wasn't a word for what he wanted to say, he simply made one up. He barded the language. For making up words, he knocks any other writer dead. When I am grown and a writer myself, as I know I shall be, I intend to Shakespeare a few words of my own. I am already practising now.

\section{Methodology}

This study focuses on the highly concentrated (sometimes 6-7 per page) nonce words in the SL and their equivalents in the TL text in Florence \& Giles. As these words are open-class words, i.e. verbs, nouns, adjectives and adverbs, we observe the grammatical categories of person, number, tense, modality, gradability, some semantic criteria, in order to define the subtypes of word classes, e.g., concrete/ abstract nouns, as well as a couple of instances of substantivization. Word-formative methods are also considered as there might be a mismatch between the word-formation processes used in the SL and TL, such as derivation, conversion, blending, composition, etc. The contrastive method when applied to the parallel corpus shows some similarities and a lot of differences in the particular characteristics of the nonce words due to the specifics of the two languages under discussion.

Newmark (1988a) proposes distinct types of neologisms; a number of them are applicable to the present study: derived words, collocations, eponyms, internationalisms, phrasal words, pseudo-neologisms, transferred words. The model of derived words is very productive as they are formed by analogy with existing word-formative patterns using prefixation and suffixation, e.g., 'wakery's, 'unslept', 'небъдница', etc. New collocations are to be translated in context: 'to beanpole' (стьрча като бобеното стъбло на Джак) or literally when they are 'transparent', e.g., 'between-the-linesed', 'good-afternoonma'amed', 'heart-in-mouthed', etc. Eponyms are proper names which are easily translated if they refer directly to a person but if they refer to qualities or

3. The examples are excerpted from the corpus of the study based on John Harding's book Florence \& Giles and its Bulgarian translation. 
ideas, the reader may need additional explanations, e.g., 'Theoing', 'Dupinned', 'Gargeried'. Internationalisms are neologisms that are universally used, e.g., 'Robinson Crusoed', 'Armageddoned', 'Rapunzelled'. Phrasal words are restricted to English and are often more economical than their translation, e.g., 'down-nosing', 'cultured away', 'offchance'. Pseudo-neologisms are old words with new senses, e.g., 'gay' meaning joyful. "They are usually translated either by a word that already exists in the TL, or by a brief functional or descriptive term" (Newmark, 1988a, p. 142). Transferred words result from transliteration of different alphabets and become 'loan words', e.g., in English 'sphinxed', in Bulgarian 'сфинксира', etc. Newly imported objects are translated like other cultural terms, usually accompanied by a generic term and a specific detail according to the readership and situation.

Being a subtype of neologisms, nonce words are difficult to translate into the TL. It is not always possible to find an appropriate analogue in the target language, which can be explained from cultural perspective or in the political situation of the corresponding countries. This research is going to study nonce words in a particular literary text, namely John Harding's novel Florence \& Giles. Additionally, this analysis will explore which of the neologism types suggested by Newmark (1988a) are attested with nonce words. We aim to reveal the similarities and differences in the use of nonce words in the original of the book and its Bulgarian translation due to language peculiarities.

\section{Data Analysis}

The corpus of the study comprises 1003 English uses of nonce words and 145 Bulgarian translation counterparts. This misbalance could be explained with the specific morphological and word-formative characteristics of the two languages. The English nonce words that are formed are mostly verbs $(85,14 \%)$ (see examples in Table 1), fewer nouns (6,19\%) (see Table 2) and adjectives $(7,67 \%)$ (see Table 3), and very few adverbs $(0,29 \%)$ (see Table 4$)$. The corresponding Bulgarian translation equivalents show fewer verbs (78\%) (see Table 1) and relatively more nouns (12\%) (see Table 2), adjectives (16\%) (see Table 3 ) and adverbs (3\%) (see Table 4) compared to the English original. ${ }^{4}$

4. The nonce words in the following examples are marked in bold. The same applies to their translation equivalents. If there is no corresponding nonce word, bold letters are not used. 
Table 1.

Nonce verbs

She laughed and then serioused ${ }^{4}$ Тя се разсмя и след това отново се again.

The sonnets weeped me. всериозничи.

Сонетите ме просълзяваха.

Giles's absence now, when young Отсъствието на Джайлс позволи на Van Hoosier and I outdoorsed, посетителя известна волност още в gave my visitor free rein with mе. първия миг, щом навънкнахме.

Table 2.

Nonce adjectives

(...) for a girl my age I am very well (..) но за момиче на моята възраст worded. Exceeding well worded, съм много добре ословесена. to speak plain. Изключително ословесена, честно казано.

No maid ever ventures here; the Прислужничките никога не стигат floors are left unbroomed, for un- дотук и подът си стои неметен, тъй footfalled as they are, what would като какъв е смисьльт, щом библиотеbe the point? ката е непристыпвана?

Table 3. Nonce nouns

So began the sneakery of my life. Така започна криеницата на живота ми.

I duly set off for the west tower, Така, (...), се отправих към западната only to be met by the most awful кула, където обаче ме очакваше ужасhope-dashery at the foot of its но надеждопопарване.

stairs.

(...) its layer of dust testifying to its (...) слоят прах по нея говореше за отlong undisturbery. давнашното ѝ неизваждане.

Table 4.

Nonce adverbs

The kitchen, where the stove is Кухнята, където от зори до мрак бумти always burny hot, is jollied by fat готварската печка, е разведрявана от $\operatorname{Meg}(\ldots)$. дебелата Мег (...).

I upped the chair and skiptoed fast Скочих от стола, изтичах на пръсти to the other side of the room and в другия край на стаята и когато stood innocenting out the window икономката влезе, невинно зяпах през when behind me the housekeeper прозореца. entered the room. 
In contrast to the definition about nonce words that they are "used in just one occasion", Florence uses some of them repeatedly, e.g., outed (22 times), downstairsed, aloned (13 times), (un)comfortabled (6 times), unmirrored (3 times), afraided, dustery, smugglery, etc. (2 times). Similarly, some translation counterparts are also repeated but not so many of them and not so often, e.g. озлочестявам (5 times), смислям (4 times), самотувам (3 times), нагоренадолувам (2 times), библиотекувам (2 times), etc.

Almost half of the nonce words appear in the first part of the text (a quarter of the book) where Florence tells the story of her difficult life and her struggle for self-education and intellectual enhancement. She only uses these words in her personal narrative, not in her direct speech with the other members of the household as she keeps her creative abilities in secret. In the second part, after the arrival of Miss Taylor in the manor, which is a turning point in the book, the occasionalisms are less in their average number as Florence is quite busy with the numerous events that happen to her, mostly initiated by herself.

\section{Key Findings}

\section{Grammatical features of nonce words}

John Harding's nonce words follow the grammatical rules of their word class. The occasional verbs here combine mostly with 1 p. sg. subjects (about 50\%), the rest of the verbs concord with 3 p. sg./ pl. or 1 p. pl. There are no 2 p. subjects as the occasional verbs are not found in Florence's conversations with other people. They are regular verbs and they are usually used in the Past Simple Tense (PST), e.g., lonelied, outdoorsed, weeped, uncleared, gianted, insincered, nervoused, eagered, etc. (see Table 5).

Table 5.

English nonce verbs used in the Past Simple Tense

I lonelied away the days, scarce able (...) но дотогава самотувах и почти to read, my whole being an impa- не можех да чета, цялото ми сьщеtience of waiting. ство тръпнеше нетърпеливо.

Giles's absence now, when young Отсъствието на Джайлс позволи на Van Hoosier and I outdoorsed, gave посетителя известна волност още в my visitor free rein with me.

The sonnets weeped me. първия миг, щом навънкнахме.

Сонетите ме просълзяваха.

But there are a few examples of nonce verbs in the Past Progressive Tense (PPT), e.g., were side-by-siding, were hide-and-seeking, was microscoping, were history-repeating-itselfing, etc., and some constructions with modal verbs, e.g., might have pleasant afternooned, would have game-upped me, could Van Hoosier the drive, etc. The following examples are presented in context (see Table 6). 
Table 6.

English nonce verbs used in the Past Progressive Tense

We were side-by-siding on a stone Един-до-другнахме на каменна пейbench beside the lake and I shifted ка на брега на езерото, но после аз се myself to other-end from him... дрьпнах в края, защото ухажването му ме дразнеше...

(...) and we were hide-and-seeking (...) така един ден, докато играехме на one day when I opened a strange криеница, отворих една непозната враdoor (...). та...

(...) which of course I could not (...) което, разбира се, все още не бях yet read - burning a hole through прочела, - можеше да се каже, че преmy bodice, we might have pleasant карахме приятен следобед. afternooned.

As for the temporal characteristics of Bulgarian equivalents, they are more varied due to the fact that Bulgarian verbs are conjugated not only in tense, aspect, voice, but also in person, number and gender. The most used are the forms of the past tenses - Aorist (A) (е.g., се въздигнах, един-до-другнахме, и се разсълзих, така си самотувах, населвах къщата, etc.) and the Past Imperfect Tense (Imp.) (е.g., заджобяваше бутилката, Гарджьросваше я, блайтваше всеки следобед, etc.), less often the Present Perfect (PrP) (e.g., съ.м втъмничила, под-кринила съм го, съм предусещала, etc.) and the Past Perfect (PР) (е.g., се беше озлочестила, се бях дюпенила, ме беше библиотекирала, etc.). Mostly active verb forms are used in both languages (see Table 7). In Bulgarian, however, cases of evidentiality are also present.

Table 7.

Tenses used in translating nonce verbs from English into Bulgarian I upped and overed (PST) to him. I Накрая, след като я изтьрва за трети irritabled (PST) out a hand. път, се въздигнах (А) и пристьпих към него.

(...) and kept any but the simplest (..) и съм втъмничила (PrP) в ума си forms of expression bridewelled всичко, освен най-простите изрази. (PST) within my brain.

For had not poor Miss Whitaker Нали горката госпожица Уитакър се tragicked (PST) a sudden and беше озлочестила (РP) с неочаквана early death with no opportunity to и преждевременна смърт, без да поmake her peace with her maker? лучи възможност да се помири със Създателя? 
The occasional adjectives are primarily non-gradable, either positive (e.g., asthmaed up, armchaired, desked, shoed feet, blanketed trips, etc.) or negative (e.g., unbooked, unviewed, unlettered, untimepieced, unpocketed, etc.) (see Table 8).

Table 8.

Nonce adjectives

I kept my fingers crossed and Стисках палци и си го представях imagined him asthmaed up at астматиран у дома, как се утешава, home, consoling himself with a bad съчинявайки някое бездарно стихоverse or two. творение.

Perhaps, after all, this boy might not Може би това момче не беше чак толbe so unbooked as he succeeded so кова безкнижно, както така добре се well in appearing; правеше;

Phrases are used felicitously as premodifiers of nouns by Florence in her idiolect because she aims at improving her creative abilities while preparing for her future occupation as a writer, e.g., a bird-in-a-cage flutter, ready-for-the-oven-chickenskin look, three-or-four-paging looks up, an out-and-out book, etc. (see Table 9).

Table 9.

Nonce premodifiers of nouns

My heart hopelessed a bird-in-a- Сърцето ми трепна обезнадеждено cage flutter. като крилце на птичка в клетка.

$\mathrm{He}$ had that ready-for-the-oven- Беше посинял като оскубано и опърchickenskin look about him again лено пиле, дробовете му стьржеха and his breath rasped like a file. като пила.

The occasional nouns are mostly abstract and they are formed as singularia tantum, e.g., dustery, foot-flickery, a twiddlery of thumbs, riskery, etc. When gerunds are used as substantives, they sometimes appear in plural, e.g., creakings, groanings, etc. (see Table 10).

Table 10.

Nonce nouns

(...) the books upon them yearning (...) по които книгите жадуват да бъfor an opening, the whole place а дат отворени, са недокосвани, всичко dustery of disregard. е прашник от немара.

(...) but I outed the room and pulled (...) но излязох от стаята и затворих the door shut after me with a skill of вратата с умело подритване.

foot-flickery. 
That night I lated awake in my bed Вечерта до късно стоях будна в легlistening to the sounds of the old лото и се вслушвах в шумовете на house as it settled itself down for the старата къща, която се нагласяше да night, the creakings and groanings заспи, проскърцваше и простенваше, as it relaxed after a hard day... отпускаше се след напрегнатия ден...

\section{Word-formation of nonce words}

The word-formative processes of nonce words provoke the interest of the linguists as they have as a result occasional words. These processes comply with the word-formation in each of the two languages, English and Bulgarian. In both languages there are simplexes (one-root words), e.g., mиfflered 'шалосваше', clumsying 'тромавее', duster 'прашник', unbooked 'безкнижно', etc., and complexes (two-root words), e.g., four-minuting 'четириминутие', pre-Whitaker 'предУитакърови', hope-dashery 'надеждопопарване', etc. English, however, also uses phrases that are turned into phraseological units, e.g., upand-downstairsing 'нагоре-надолувам', side-by-siding 'един-до-другнахме', two hundred-Shakespeare 'двестния Шекспир', etc. The most common wordformation method of the nonce words created by John Harding is conversion, i.e. zero derivation, a method that is non-existent in Bulgarian. Hence, the equivalents in the TL are formed by affixation. Affixation is also found in the nonce words of the SL but it is limited in scope.

The occasional verbs are mostly formed by conversion in English. The sources are mainly adjectives, e.g., difficult $\rightarrow$ to difficult; tedious $\rightarrow$ to tedious; impatient $\rightarrow$ to impatient; anxious $\rightarrow$ to anxious, etc. (see Table 11).

Table 11.

Adjective-to-verb conversion

With this promise of salvation, В това отношение снегьт ми донесе though, the snow difficulted me in обещание за спасение, но пък ме отanother way. рудни в друго.

It tedioused having to go right Досади ми, че трябва да сляза на пърdown to the first floor and then up вия етаж и оттам да се кача на втория again to the second

I anxioused as I reached for the Притеснено посегнах към въжето на bell pull. звънеца.

Nouns are also used as sources of conversion to give rise to verbs: winter $\rightarrow$ to winter; brain $\rightarrow$ to brain; problem $\rightarrow$ to problem; puppy $\rightarrow$ to puppy, etc. (see Table 12). 
Table 12.

Noun-to-verb conversion

I had never wintered much in the Преди не бях зимувала в библиотекаlibrary, because it had no fire... та, тъй като там не се палеше...

(...) just when I thought to have re- (...) точно когато си мислех, че найcovered them, when I brained an сетне съм си ги върнала, и в тоз миг idea. ми щукна идея.

But soon as Theo Van Hoosier began Но след като започнаха посещенията to call, the afternoons problemed на Тео Ван Хузиър, следобедите отноme anew. во ме възтрудниха.

Sometimes adverbs are converted into verbs: away $\rightarrow$ to away; out $\rightarrow$ to out; inward $\rightarrow$ to inward; together $\rightarrow$ to together; down $\rightarrow$ to down, etc. (see Table 13).

Table 13.

Adverb-to-verb conversion

As soon as he awayed from Blithe, Оставеше ли Блайт зад гърба си, той he would tell. щеше да проговори.

I outed to the hall and hung it with Излязох в коридора и я закачих при his coat. палтото му.

This recovery was good by Theo's По неговите стандарти това сигурно standards but I inwarded a curse... минаваше за добро оправдание, но аз мълчаливо го проклех...

Prepositions, too, can become verbs in Florence's narrative: $n$ ext $\rightarrow$ to next; up $\rightarrow$ to $\mathrm{up} ;$ over $\rightarrow$ to over; between $\rightarrow$ to between; beneath $\rightarrow$ to beneath, etc. (see Table 14).

Table 14.

Preposition-to-verb conversion

He came and nexted me on the couch.

I upped and overed to him. I irritabled out a hand.

She (...) took out another cookie, which she betweened her teeth to freehand herself...
Той се приближи и седна до мен на дивана.

Накрая, след като я изтьрва за трети път, се въздигнах и пристъпих към него.

(...) взе още една сладка, пъхна я между зъбите си, за да освободи ръката си... 
Additionally, proper nouns are converted into verbs, e.g., I could Van Hoosier the drive; I had to be one-Shakespearing-two-Shakespearing; He sat and Gargeried it, etc. (see Table 15).

Table 15.

Proper noun-to-verb conversion

No matter, if I sat at the desk, I Ако седнех на писалището, можех да could Van Hoosier the drive. бдя за Вай Хузиър.

Not only that, all the while I had И не само това, а и през цялото време to be one-Shakespearing-two- трябваше да нареждам: „Един ШеShakespearing кспир, втори Шекспир“...

I had Dupinned it right! Правилно се бях дюпенила!

Conversion is not found in the TL because of the morphological structure of Bulgarian, but instances of affixation are used instead, e.g., се бе озлочестила, разгнездвам, всериознича се, вщрауся се, смисля, etc. According to Savova (2016, p. 97), the most common is the formation of occasional verbs from source nouns to which suffixes are added, less often prefixes, and sometimes both prefixes and suffixes, e.g., омаловъзможничавам. The following prefixes are used $\varepsilon_{-}$, въз-, за-, из-, $о-$, , об-, от-, nо-, под-, etc., and the applied suffixes are

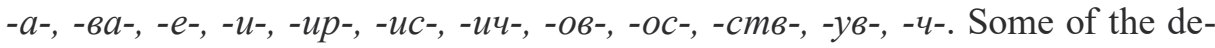
nominal verbs are библиотекувам, възпринцеся се, кулосвам, остихотворя, отбрашня, сфинксирам, etc. In the SL, affixed denominal nonce verbs are only found with negative prefixes, e.g., to denest, to deculture, to deshelf, to unlibrary) or suffixes, e.g., to fruitless. Verbs deriving from nouns with negative prefixes are also used in the TL, e.g., обезкултуря, обезкапача, обезплодя, etc. (see Table 16).

Table 16.

Nonce verbs with negative prefixes

(...) until the clock struck the quar- (...) докато часовникът не удареше един ter hour before one, when I den- без петнайсет, и тогава се разгнездвах, ested, slipped from the room and измъквах се от стаята и отивах да обядhurried to lunch. вам.

He pretty much decultured himself И доколкото мога да преценя, самият too, той се обезкултурил.

Nonce verbs come from proper nouns in the TL via affixation: Ван Хузиърувах, се бях дюпенила, шекспирам, Гарджъросваше я, предУитакърови дни. 
Similarly to other transformations of nouns into verbs, in these cases verbal suffixes are used: $-a-,-b a-,-y b-$, etc.

Affixation also turns other parts of speech into nonce verbs in the TL. Examples of deadjectival TL verbs that make use of affixation are: въз-трудн-я, о-злочест-я се, из-любезн-ич-а, самот-увам, о-дързост-я, etc. (see Table 17). In the SL affixed deadjectival verbs are only formed with the negative prefix un-, e.g., to untranquil, to unclear, to unlikely, to unnecessary, etc. Otherwise, deadjectival verbs are formed by conversion, e.g., lonelied, opposited, stubborned, etc.

Table 17.

TL nonce verbs formed through affixation

So I lonelied my way round the big Така си самотувах в голямата къща, house, opening doors and disturbing обикалях из неспаните спални и разthe dust in unslept bedrooms. движвах прахоляка в тях.

(...) but her refusal to help me, far (...) но отказът й да ми помогне не ме from discouraging me, opposited, обезкуражи, а наопаки, само заинати and merely stubborned my resolve. решителността ми.

The TL nonce verbs that have derived from adverbs are втьмнича, навънквам, нагоре-надолувам, etc. They also accept both prefixes and suffixes due to the morphological specifics of the Bulgarian language: в-тъмни-ча, навън-к-вам, нагоре-надолу-вам, еtс. The SL verbs that originate from adverbs are few and they are transformed by conversion, e.g., lated, downstairsed, upstairsed, and composition + conversion, e.g., no-furthered, up-and-downstairsed, out-ofsighted (see Table 18).

Table 18.

SL nonce verbs formed through composition and conversion

(...) invisibling me from any who (...) оставах невидима за тези, които stood there, providing, of course, стояха на прага, стига, разбира се, да they no-furthered into the room. не навлезеха в стаята.

On a good book such as Jane Eyre При хубавите книги като „Джейн I might be up-and-downstairsing Еър“ например се случваше да нагоfour or five times in an afternoon.

ре-надолувам по стълбите по четири пет-пьти за един следобед.

Different variants of affixation techniques are applied to TL verbs to give rise to occasional verbs, a prefix is added where none is expected, e.g., осмутя, излюбезнича, поглавобльскам, etc. Sometimes the original prefix is replaced, 
е.g., въздигам се, разбудвам, разсълзих се; in other cases more than one prefix is added to the verb base, e.g., о-без-плодя, о-без-културя, о-без-капача. In still other cases, apart from adding an unexpected prefix, the verb has lost its reflexive particle ce (see Table 19).

Table 19.

TL nonce verbs transformed from reflexive into non-reflexive

It obvioused Miss Taylor would Не усъмнявах, че госпожица Тейлър by now have found the cloak, for вече я е открила, тъй като нямаше как she could not have brushed her hair да се среше, без да я зърне, without doing so,

The opposite process is observed in the SL for the nonce verbs are very often reflexive, e.g., to ballet herself, to practical myself, to library myself, to couch himself, to overbanister myself, etc. (see Table 20).

Table 20.

SL nonce verbs transformed from non-reflexive into reflexive

but saw a small girl, such as I must а виждах малко момиченце, каквото once have been, whom I imagined съм била и аз навремето, представях in a white frock with a pale face си го с бяла рокля и отиващо си с нея to match, balleting herself lightly бледо лице, как балетисва с лекота по across the bare boards. голите греди.

There is a group of occasional verbs that are compounds originating from phrases. They are spelled either as one word or hyphenated, e.g., to upstairs/ downstairs, to cheesegrate, to beanpole, to sudden-fright, to long-corridor, to loud-and-clear, to heart-in-mouth, to next-door, to deep-breath, to coast-clear, etc. The corresponding Bulgarian equivalents are fewer in number but as innovative as the originals, e.g., главобльскам се, нагоре-надолувам, един-додругвам, etc. In their word-formation, composition, blending and suffixation are used. Unlike the English compounds, the Bulgarian ones contain a linking vowel, e.g., глав-о-блъскам се, and a suffix, е.g., един-до-друг-вам.

Most nonce adjectives in the SL follow the word-formative patterns of participle adjectives. The main difference, however, is that they are not derived from verbs. The occasional adjectives originate basically from nouns, conforming to the formula $\mathrm{N}+$-ed/ -ing = Adj., e.g., worded, desked, booked, musicked, poetried, theatred, philosophied, librarying years, etc. In the other common model, adjectives are derived from adjectives, according to the pattern Adj. + 
-ed = Adj., e.g., darked, alouded, restlessed, etc. Compound nouns of the SL are combined with the grammatical marker -ed and sometimes with the negative suffix un- to make up nonce adjectives, e.g., wingbacked, armchaired, unfootfalled, unfingerprinted, etc.

In the TL occasional adjectives originate mainly from nouns and less frequently from verbs and phrases. No cases of nonce adjectives derived from verbs are attested in the SL corpus because they would coincide in form with standard language participles and would not result in nonce words. The translation instances are more diverse due to the multiple suffixes used in adjectival word-formation, e.g., -ан-, -ен-, - ест-, -лив-, -ск-, -тел-ен-, as well as the prefixes за-, из-, не-, $o-$. When the occasional adjectives have the form of a participle, they use the suffix -н-, e.g., астматиран, неспан, отеатрен, etc. Denominal adjectives are such examples as паяжинест, закулен, принщесешки, убежищен, одеален, etc. The following adjectives are derived from verbs: течлив, непристьпван, смутителен, etc. Composition, together with affixation, is used to derive nonce adjectives from phrases in the TL: ивет-о-поливаш, глав-о-трошач-ески, негост-о-пропуск-лив, без-гувернант-ен, без-джоб-ен. In most of the cases the linking vowel $-O$ - is used. No linking vowel is used in the word-formation of occasional adjectives deriving from phrases in the SL; hyphenation is used instead, e.g., an out-and-out book, a bird-in-a-cage flutter, stupid-seeming, threeor-four-paging days, ready-for-the-oven-chickenskin look, etc.

Occasional nouns in the SL are formed from nouns or verbs, in most of the cases these are homonymous nouns and verbs derived through conversion. The suffix -(e)ry is added to the root morpheme to make an abstract noun, e.g., to sneak - sneak - sneaker, to quiz - quiz - quizzery, to risk - risk - riskery, to drip - drip - drippery, to squeeze - squeezery, to eavesdrop - eavesdroppery, to budge - budgery, a whim - whimmery, a purse - pursery, a blanket - blanketry, etc. There are also prefixed nonce nouns, e.g., unlockery, unheedery, unseenery. Compound occasional nouns result from transformed collocations, e.g., to twist fingers - finger-twistery, to flick feet-foot-fickery, to dash hopes - hope-dashery, to hold one's breath - breath-holdery, to trip in a rug - rug-trippery, long legs - leg-lengthery, a howl of wind - wind howler, etc. Additionally, nonce nouns take part in Noun phrases of the type Determiner + Noun + of + Noun, which could be interpreted as paraphrased clauses e.g., puzzlery of papers (papers that make a puzzle), burnery of summer (summer that burns one's skin), a sneezery of dust (dust that makes one sneeze), fadery of twilight (twilight that fades), a smugglery of books (a lot of books where one can smuggle), a twiddlery of thumbs (to twiddle one's thumbs), a weepery of frustration (to weep because of frustration), a flingery of arms (to fling one's arms), a frustratory of captions (captions that cause frustration), etc. However, the occasional nouns in the TL show wider variation in word-formative processes having derived from nouns, verbs, adjectives and phrases with the help of suitable prefixes 
and suffixes or through composition, e.g., враг - врагиня, прах - прашник, Тео - теосване, бъда - небъдница, труден - отруднение, единичен единачество, появявам се - непоява, изваждам - неизваждане, свъртам се - несвъртане, въртоглав - въртоглавие, сладокусен - сладокусница, четири минути - четириминутие, прегрьдки и целувки - прегръдкоцелувки, попарвам надежди - надеждопопарване.

The SL nonce adverbs originate from adjectives, e.g., innocent - stood innocenting, or verbs, e.g., to burn - burny hot, while the TL occasional adverbs derive from nouns, e.g., копнежно, adjectives, e.g., смутително, отруднено, or phrases, which are blended and accompanied by suffixes, e.g., презпрозоречно.

Semantic transformations from the SL into the TL

The meanings of most occasionalisms coined by Florence are transparent as there is a direct relation between the new and the original word even out of context (see Table 21):

Table 21.

Nonce words with clear meaning out of context ungovernessed (adj.) $\leftarrow$ a governess (n) безгувернантни (adj.) $\leftarrow$ гувернантка (n) unslept (adj.) $\leftarrow$ to sleep (v) an unheedery $(\mathrm{n}) \leftarrow$ heed $(\mathrm{n})$

$\operatorname{accidenting}(\mathrm{n}) \leftarrow \operatorname{acciden} \mathrm{n}(\mathrm{n})$ to stubborn $(\mathrm{v}) \leftarrow$ stubborn (adj.)

to serious $(\mathrm{v}) \leftarrow$ serious (adj.) to deculture $(\mathrm{v}) \leftarrow$ culture $(\mathrm{n})$ неспан (adj.) $\leftarrow$ спя (v) незабележителност забележителност (n) злополучие (n) Ł злополука (n) озлочестя (v) $\longleftarrow$ злочест (adj.)

всериозничи се $(\mathrm{v}) \leftarrow$ сериозен (adj.) обезкултуря (v) Ł култура (n)

In some cases complex, compound or phrasal occasionalisms have their meaning conditioned by an original collocation (see Table 22):

Table 22.

Nonce words derived from collocations

to outdoorse $(\mathrm{v}) \longleftarrow$ go out of door навънквам (v) $\longleftarrow$ излизам навън one's leg-lengthery (n) $\leftarrow$ length of legs дългокрачието си (n) $\leftarrow$ дълги крака hope-dashery (n) $\leftarrow$ to dash s.o.'s надеждопопарване (n) $\leftarrow$ попарване на hope надежди asthmaed up (adj.) $\longleftarrow$ having asthma астматиран (adj.) $\longleftarrow$ болен от астма 
Still the meaning of the occasional words is clear because the omitted elements (prepositions, pronouns, etc.) do not play a decisive role in the semantics of the collocation. Additionally, these new words stand out against collocations with their brevity and conciseness. Other instances of nonce words are understood only in context (see Table 23):

Table 23.

Nonce words understood only in context

Once on board, he sat in his seat, Качи се, настани се на седалката, усwindowing us with smiles and михваше се и ни махаше презпрозоwaves, and I bit my lip and did my речно; прехапах устни и се постарах best to smile him back, и аз да се усмихна,

It was for me, and I reflected that То беше за мен и нямаше как да не си from being completely unlettered помисля, че допреди няколко седмиbut a few weeks ago... ци бях напълно безписмовна...

Perhaps, after all, this boy might not Може би това момче не беше чак толbe so unbooked as he succeeded so кова безкнижно, както така добре се well in appearing; правеше;

She wasn't there long before she got Не след дълго тя вече била олитераherself booked... турена...

The meaning of the verb 'to window' may not be figured out correctly as the dictionary definition 'to place at or in a window' is not applied literally. It should be interpreted as 'he sat in his seat, smiling and waving at us through the window'. In Bulgarian 'презпрозоречно' can only be understood in collocation with the verb 'махаше'. 'Unlettered' is ambiguous between lacking a letter as a symbol of an alphabet or written communication. The Bulgarian adjective 'безписмовна' is unclear in an analogical way because the meaning is also split between без писменост 'without alphabet' and без писма 'without letters'. The verb 'to book' is polysemous but an additional meaning is coined here: '(un) booked - having read (no) books'.

The semantics of nonce words that have been derived from proper nouns which denote characters in the novel depends on the context (see Table 24).

Table 24. Context-dependent nonce words derived from proper nouns

if they were unHoosiered, upglance ако в тях нямаше и следа от Ван Хузиthe drive, and if that were likewise ьр, да погледна алеята и ако тя също Theo-free, make the mad dash up to беше обезТеоена, отново да хукна the tower again. към кулата. 
But Giles leaving home and all the Но заминаването на Джайлс и моето Theoing I'd had had changed all теосване бяха променили всичко. that. I saw that now.

Meanwhile I read all the mornings Междувременно четях по цял преand some of the afternoons and then диобед и в някои от следобедите, а Van Hoosiered my way through the през останалите Ван Хузиърувах. rest.

No matter, if I sat at the desk, I could Ако седнех на писалището, можех да Van Hoosier the drive бдя за Вай Хузиър

The adjective 'Theo-free', the non-finite form 'Theoing' and the verb 'Van Hoosiered' as well as their Bulgarian equivalents 'обезТеоена', 'теосване', 'Ван Хузиърувах', have these particular meanings only in this context. The composite 'Theo-free', the complex adjective 'обезТеоена', the gerund 'Theoing' and the deverbal noun 'теосване' derive from the proper name Theo. Both the suffix '-free' and the prefix 'без-' when combined with the name mean 'without Theo'. The pair 'Theoing' and its counterpart 'теосване' function as verbal nouns in the context and are interpreted as 'making friends with Theo'. The family name Van Hoosier gives rise to the verb 'Van Hoosiered' / 'Ван Хузиърувах' which is used polysemantically to mean, on the one hand, 'to meet Van Hoosier' and 'to watch for Van Hoosier', on the other hand. Another case of polysemy is attested when an occasional verb is formed from the name of Shakespeare (see Table 25):

Table 25.

Nonce words derived from Shakespeare

I intend to Shakespeare a few Когато порасна и стана писателка, в words of my own. което изобщо не се съмнявам, ще шекспирам нови думи.

who would have thought I Frenched Кой би предположил, че франкофонand Shakespeared?), ствах и шекспирех?

Not only that, all the while I had И не само това, а и през цялото време to be one-Shakespearing-two- трябваше да нареждам: „Един ШеShakespearing and if someone кспир, втори Шекспир“, и ако ме заshould speak to me and I should говореха и изгубех бройката, lose my number,

The context of the phrase 'to Shakespeare a few words' / 'ще шекспирам нови думи' suggests that it should be interpreted as 'to create new words as Shakespeare does', while 'I Frenched and Shakespeared' / 'франкофонствах и шекспирех' would mean 'I studied French and read books by Shakespeare'. Using Shakespeare in counting, e.g., 'one-Shakespearing-two-Shakespearing' 
resembles the children's practice to approximate the passing of a second as in 'one Mississippi, two Mississippi'. Because the word is so long, the intervals between the numbers are around one second of time. It is traditionally used by children playing hide-and-seek to count the hiding-time period. The fact that in Florence's imagination Shakespeare takes part in all kinds of nonce words is indicative of her constant preoccupation with English literature.

Florence's deep fascination with literature surfaces in some other nonce words (see Table 26):

Table 26.

Nonce words derived from literary characters

I had Dupinned it right! Правилно се бях дюпенила!

He sat and Gargeried it, twisting it Гарджъросваше я, мачкаше я, върthis way and that, теше я на едната си ръка с палеца и показалеца на другата,

In order to understand the meaning of the occasional verb 'to Dupin' / 'дюпеня ce', the reader should relate it to the fictional character created by Edgar Allan Poe, who appears in a few short stories. Dupin is the prototype of the fictional detective being able to put himself in the mind of the criminal but also combining considerable intellect with creative imagination. Therefore, the meaning of the verb should be figured out as 'to make logical inferences and reasonable conclusions'. To make it clearer to the Bulgarian reader the translator has included a footnote which says "Dupin is a character of several stories by $\mathrm{E}$. A. Poe, in which he solves intricate mysteries through deduction." A similar verb is 'to Gargery' / 'Гарджъросвам' that originates in Mrs Gargery's name, a character from Charles Dickens's Great Expectations. Mrs Gargery has become a nickname for violent and cruel behaviour, hence the newly coined word has the sense of 'treating s.o./ sth ferociously'. To avoid misunderstandings the Bulgarian translator has provided an explanatory note about Mrs Gargery and what her name stands for.

Other more general eponyms rely on the readers' background knowledge to interpret the correct meaning of the nonce word (see Table 27):

Table 27.

Nonce words based on the readers' background knowledge ... that he would not be pay- (...) и той да не е в състояние да дойде, ing me another visit before I преди да настъпи моят Армагедон c Armageddoned with the govern- гувернантката. ess. 
It was a long afternoon and al- Следобедът се точеше едва-едва, а аз though I Robinson Crusoed the като същински Робинзон Крузо се drive, squinting to see a friendly взирах с присвити очи навън с надежsail, дата да зърна приятелско платно,

I stood there now, mistress of all I Стоях там, господарка на всичко, surveyed, fairytaled in my tower, което се разстилаше пред погледа ми, Rapunzelled above all my known Дългокоска в своя приказен замък, world. извисена над целия си познат свят.

he beanpoled above me, which did (...) стърчеше над мен като бобеното not endear him to me, стъбло на Джак,

The occasional verb 'to Armageddon' relies on some general knowledge of both English and Bulgarian readership about the New Testament and more specifically about the last battle between good and evil before the Day of Judgement. The use of the name of Robinson Crusoe as a verb requires the reader to know that he is a shipwrecked sailor from Daniel Defoe's eponymous novel, who lives for many years on an uninhabited island. Similarly, in order to understand the association with Rapunzel, one should be familiar with the fairytale about a young woman with impossibly long hair who lives alone in a tower because she is held captive by a witch. The Bulgarian equivalent refers descriptively to the fairytale using a nickname for the main character 'Дългокоска' (long-haired). Another descriptive transfer we find with the composite nonce verb 'beanpoled'. It is expected by the native English speakers to know the classic fairytale about a poor country boy who exchanges the family cow for a few magic beans, which grow into an enormous beanstalk. The translator helps the Bulgarian readership by providing a direct reference to Jack and the Beanstalk 'като бобеното стъбло на Джак'.

\section{Conclusion}

Summing up the analysis of the peculiarities of author's occasionalisms it should be taken into account that the differences in the original and translated nonce words are due to the distinctions in the morphology and word-formation models of Bulgarian and English. The most widely used word-formative patterns in English are conversion and composition, sometimes collocations and whole quotation groups are turned into nonce verbs. Rarely, derivation is used to form negative verbs and adjectives through prefixation with de- and un-, and deverbal nouns with the suffix -ery. Bulgarian relies heavily on derivation as it uses a wide variety of prefixes and suffixes for word-formation. In the lexical systems of English and Bulgarian there are discrepancies, which are manifested in the meaning of the word, where languages often highlight different features 
of the same phenomenon or concept, which reflects the vision of the world inherent in this language. In other words, it is difficult for native speakers of specific languages to translate occasionalisms; in the present corpus only $15 \%$ of the English nonce words have translation counterparts, which are nonce words. However, the Bulgarian translation of Florence and Giles has managed to capture the spirit of the narration and convey it in another language. The translator is also a co-author because following John Harding's example he actually created his own occasionalisms in Bulgarian.

\section{References:}

Anderson, J. M. (2006). The Linguistics encyclopedia (Ebook). Malmkjær, K. (Ed.). London: Routledge.

Boyadzhieva, E. B. (2017). Name symbolism and the Bulgarian translations of Terry Pratchett's Discworld characters. International Scientific and Practical Conference World science, T. 2, N 8 (24), 16-31.

Eckler, A. R. (1971). Words, non-words, nonce words. Word Ways, 4(2), Article 17. Gorchhanova, A. (2016). Osobennosti perevoda okkazionalizmov. Moskva, 34-123.

Harding, J. (2010). Florence \& Giles. London: HarperCollinsPublishers.

Holtvian, V., \& Severynchuk, I. (2015). Nonce vocabulary items as untranslatables or translatables in Ukrainian - English media communication. Humanity, computers and communication (HCC'2015), 22-24 April 2015, Lviv, Ukraine.

Iglikova, R. (2013). The (In)translatability of wordplay and the loss of humorous effect in the Bulgarian translation of Terry Pratchett's Soul Music. In Pancheva, E., Stamenov, Ch., Pipeva, M., \& Niagolov, G. (Eds.), Peregrinations of the Text: Reading, Translation, Rewriting (pp. 356-363). Sofia University.

Lugovaya, E. A. (2016). Proper names as author's occasionalisms in J. R.R. Tolkien's novel The lord of the rings. Vestnik stavropol'skogo gosudarstvennogo pedagogicheskogo institute. Stavropol': Stavropol'skiy gosudarstvennyy pedagogicheskiy institute, 294-300.

Nedelcheva, S. (2017). Translation strategies in The Lord of The Rings. Twelfth International Scientific Conference KNOWLEDGE WITHOUT BORDERS 31.3-2.4.2017, Vrnjacka Banja, Serbia.

Newmark, P. A. (1988a). Text book of translation. Prentice Hall International (UK) Ltd.

Newmark, P. (1988b). Approaches to translation. Hertfordshire: Prentice Hall.

Newmark, P. (1991). About translation: Multilingual matters. Clevedon, Philadelphia, Adelaide: Multilingual Matters Ltd. 
Nida, E. A. (1964). Towards a science of translation, with special reference to principles and procedures involved in Bible translating. Leiden: Brill.

Petrov, D. (2019). Occasionalism interpretation in speculative fiction as a problem based upon the J. R. R. Tolkien Lord of the rings, The two towers. Nauchnyy Al'manakh, 11-12 (61), 238-241.

Pope, M. (1985). A nonce-word in the Iliad. The Classical Quarterly, 35(01), 1-8. DOI: $10.1017 /$ S000983880001449X

Romanyuk, M. (2019a). Phonetic occasionalisms in the works of J. Rowling. Modern Studies of Social Issues, 11(4-2), 98-101.

Romanyuk, M. (2019b). Occasional word formation according to non-standard models in the works of J. Rowling. Modern Studies of Social Issues, 11(3-2), 44-48.

Savova, I. (2016). Occasionalisms in the text structure (an observation of a novel). Otgovornostta pred ezika, T. 4, 87-104.

Starikova, T. (2019). Methods of transferring spells in the novel of J. Rowling Harry Potter and the cursed child (in translation from English into Chinese). Filologicheskiy aspect, 7 (51), 96-103.

The Translation of English Neologisms. Terminology Coordination Unit [DGTRAD]. European Parliament, 22 June 2015. 